\title{
Prevalence of Newcastle disease virus in feces of free-range turkeys in Enugu, Nigeria
}

\author{
Obianuju Nkiruka Okoroafor ${ }^{1}$ (D), Paul Chukwuemeka Animoke ${ }^{1}$ (D), Edmund Chidiebere Mbegbu²(i), \\ Chinwe Justina Aronu ${ }^{3}$ (D) John Anelom Nwanta ${ }^{(\mathbb{D}}$, Boniface Anene ${ }^{1(\mathbb{D})}$ and John Ositadimma Okoye ${ }^{5}$ (D)
}

\begin{abstract}
1. Department of Veterinary Medicine, Faculty of Veterinary Medicine, University of Nigeria, Nsukka, Nigeria; 2. Department of Veterinary Physiology and Pharmacology, Faculty of Veterinary Medicine, University of Nigeria, Nsukka, Nigeria; 3. Department of Animal Health and Production; Faculty of Veterinary Medicine, University of Nigeria, Nsukka, Nigeria; 4. Department of

Veterinary Public Health, Faculty of Veterinary Medicine, University of Nigeria, Nsukka, Nigeria; 5. Department of Veterinary Pathology and Microbiology, Faculty of Veterinary Medicine, University of Nigeria, Nsukka, Nigeria.

Corresponding author: Obianuju Nkiruka Okoroafor, e-mail: obianuju.okoroafor@unn.edu.ng

Co-authors: PCA: paul.animoke@unn.edu.ng, ECM: edmund.mbegbu@unn.edu.ng, CJA: chinwe.aronu@unn.edu.ng, JAN: john.nwanta@unn.edu.ng, BA: boniface.anene@unn.edu.ng, JOO: joaokoye@yahoo.com

Received: 30-11-2019, Accepted: 14-05-2020, Published online: 08-07-2020
\end{abstract}

doi: www.doi.org/10.14202/vetworld.2020.1288-1293 How to cite this article: Okoroafor ON, Animoke PC, Mbegbu EC, Aronu CJ, Nwanta JA, Anene B, Okoye JO (2020) Prevalence of Newcastle disease virus in feces of free-range turkeys in Enugu, Nigeria, Veterinary World, 13(7): 1288-1293.

\begin{abstract}
Background and Aim: Newcastle disease (ND) virus of free-range turkeys may be linked to outbreaks of ND in backyard chickens seen during Harmattan in Enugu State in Southeast Nigeria. This study aimed to determine the prevalence of ND virus and (NDV) detect NDV in the feces of free-range, domestic turkeys in Enugu, Nigeria.

Materials and Methods: A total of 569 serum and 569 cloacal swab samples were collected from adult turkeys in selected households that keep turkeys and chickens together in the study area. The serum samples were assayed for antibodies against NDV using the hemagglutination inhibition (HI) test, whereas the cloacal samples were subjected to virus detection using a hemagglutination (HA) test.
\end{abstract}

Results: A total of 186 serum samples (32.7\%) were positive for NDV and $383(67.3 \%)$ were negative. Of the 186 NDV-positive serum samples, $138(74.2 \%)$ had HI titers $\geq 8$. The remaining $48(25.8 \%)$ serum samples had HI titers $<8$. NDV was detected from the cloacal swabs of turkeys with NDV -positive serum samples.

Conclusion: The turkeys in this study were not previously vaccinated with the NDV vaccine; thus, those with NDV -positive serum samples and virus shedding in their feces may be potential risks to chickens reared in the same households as well as on commercial farms in the area. Those turkeys with sera negative for NDV are regarded to be at risk if they encounter a virulent strain of NDV. Regular vaccination of turkeys against the NDV is advised, especially in backyard farms, where turkeys are reared together with chickens and other species of poultry.

Keywords: Newcastle disease, prevalence, turkeys, virus shedding.

\section{Introduction}

Newcastle disease (ND) is the most devastating viral disease of poultry, especially in developing countries, where the majority of the flock is raised on an extensive management system [1]. The disease is caused by Newcastle disease virus (NDV), an avian orthoavulavirus 1 that belongs to the genus orthoavulavirus, in the subfamily Avulavirinae, and family Paramyxoviridae [2,3]. More than 200 species of birds have been reported susceptible to natural and experimental infection with NDV, and it seems probable that more may be susceptible [3]. Chickens are most susceptible; turkeys are less susceptible; and quails, geese, and ducks are more resistant [4-8]. The spread and threat of ND to the poultry industry have

Copyright: Okoroafor, et al. Open Access. This article is distributed under the terms of the Creative Commons Attribution 4.0 International License (http://creativecommons.org/licenses/ by/4.0/), which permits unrestricted use, distribution, and reproduction in any medium, provided you give appropriate credit to the original author(s) and the source, provide a link to the Creative Commons license, and indicate if changes were made. The Creative Commons Public Domain Dedication waiver (http:// creativecommons.org/publicdomain/zero/1.0/) applies to the data made available in this article, unless otherwise stated. been attributed mainly to commercial poultry reared in intensively managed poultry systems. Recently, attention has been drawn to scavenging village poultry species when various strains and pathotypes of NDV were isolated from apparently healthy village chickens, ducks, and quails [9,10]. Echeonwu [11] reported the isolation of a highly velogenic strain of NDV from apparently healthy ducks in Nigeria, which has been incriminated in the ND field and experimental outbreaks in chickens associated with very high mortality and morbidity. Thus, domestic chickens and other poultry species have been incriminated as sources of the spread of NDV [12-14]. Similarly, the ND outbreak of 1984 in the United Kingdom was found to be due to unvaccinated birds consuming feed contaminated by feces of infected pigeons [15], and in Nigeria, ND outbreaks have been linked to farms that rear exotic birds with local chickens, turkeys, and other avian species [16]. This shows that the spread of NDV in ND outbreaks witnessed in Nigeria, especially during the Harmattan season (mid-November through March) [17], is linked to rural community settings where a combination of different species and 
breeds of poultry such as chickens, turkeys, Muscovy ducks, and pigeons is reared together in the same compound [18]. This is also the case in cities where exotic poultry such as ostriches, peacocks, geese, and mallard ducks are kept together in the same compound and on some poultry farms [19]. The corearing of different species of poultry can facilitate the introduction and spread of NDV among poultry species and breeds in Nigeria as suggested by other researchers $[12,19]$.

In Enugu state of Southeast Nigeria, it is also a common practice for households and even commercial farms to keep turkeys alongside local and exotic poultry. Outbreaks of ND have been reported in our current study area in addition to other parts of Nigeria in both rural and city settings, especially during Harmattan [17], and it is characterized by severe loss of both commercial and local poultry. These outbreaks in chickens have been linked to other species such as the pigeon in Great Britain [15] and turkeys in Indonesia [20], but in Nigeria, there is limited information on the susceptibility of turkeys to NDV and the role played by turkeys in transmitting the virus to other species.

This study aimed to investigate the presence of ND antibodies in the sera and NDV in the feces of turkeys to provide information on the role of turkeys in the ND outbreaks commonly seen in both local and exotic chickens in Enugu state of Southeast Nigeria.

\section{Materials and Methods}

\section{Ethical approval and informed consent}

Ethical approval for this study was given by the University Committee on Medical and Scientific Research Ethics, University of Nigeria, Nsukka. Written and signed consent were given by the turkey keepers before the study was conducted.

\section{Study area}

The study was conducted in Enugu state, Southeast Nigeria (Figure-1). Enugu state is located between latitudes $5^{\circ} 56^{\prime} \mathrm{N}$ and $7^{\circ} 55^{\prime} \mathrm{N}$ and longitudes $6^{\circ} 53^{\prime} \mathrm{E}$ and $7^{\circ} 55^{\prime} \mathrm{E}$. It covers a total land area of about $802,295 \mathrm{~km}^{2}$ and has a population of 2.5 million with a population density of 248 persons/ square kilometer. The wet season lasts from April to October, while the dry season lasts from October to early April. The predominant poultry species kept is chickens (local and exotic), others are turkeys and ducks. These poultry species are reared intensively, semi-intensively, or on free-range system of management. Households that keep turkeys with other species and showed a willingness to be part of the study were purposively selected.

\section{Study period, location and study population}

The study was conducted from March to October 2014. Adult turkeys kept in households that rear poultry, in randomly selected communities in the east, west, and north senatorial zones of Enugu state were chosen for this study. The turkeys selected had no previous history of NDV vaccination.

\section{Sample size, determination, and design}

A total of 569 turkeys were sampled in the study area. The sample size was determined according to the previous methods [21] with a $95 \%$ confidence interval and 5\% absolute precision.

\section{Sample collection}

Turkeys are not routinely kept commercially in the study area; therefore, we were constrained to collect blood and cloacal samples from 20 adult turkeys per household visited. Blood samples were collected in sterile tubes without ethylenediaminetetraacetic acid (EDTA) and immediately sent to the department of veterinary medicine laboratory to harvest serum.

\section{Laboratory examinations}

Blood $(1 \mathrm{~mL})$ was collected from each adult turkey sampled per household visited; serum was harvested and used in hemagglutination (HA) and hemagglutination inhibition (HI) tests. Cloacal swabs were collected from the same adult turkeys from which blood samples were collected and used for NDV detection using HA test. All fecal samples that showed HA were positive using known NDV antiserum [22].

\section{Statistical analysis}

HI antibody titers $>8$ were considered positive [23]; thus, the numbers and percentages of turkeys at risk were calculated. Individual HI titers between the zones were compared by one-way ANOVA, and variant means were separated by Duncan's multiple range test. Significance was accepted at $p<0.05$.

\section{Results}

Of the 569 serum samples collected from adult turkeys in households that keep turkeys and chickens in Enugu state, 186 (32.7\%) were positive for antibodies to NDV. Thus, $32.7 \%$ of the total serum samples collected from the three senatorial zones of Enugu state were positive, whereas 383 (67.3\%) serum samples were negative for antibodies to NDV (Table-1). The mean ND HI antibody titer in free-range turkeys sampled in East Enugu (579.41 \pm 98.46$)$ was significantly $(p<0.05)$ higher than that of the west $(61.89 \pm 11.69)$ and north $(85.92 \pm 28.58)$ senatorial zones (Table-2).

Of the 186 serum samples with detectable antibody titers against NDV, 138 (74.2\%) had geometric mean HI titers $\geq 8$ and were presumed to be protected against field challenge with NDV, whereas the remaining 48 (25.8\%) serum samples had HI antibody titers $<8$ and were presumed to be at risk (Table-3).

NDV was detected from the cloacal swabs of turkeys that had ND HI-positive sera in all of the households that kept both turkeys and other avian species together in the study area (Table-4).

\section{Discussion}

Detection of ND hemagglutinating antibodies in unvaccinated turkeys sampled in the study area 
Table-1: Prevalence of Newcastle disease virus antibodies in free-range turkeys in the three senatorial zones of Enugu state, Southeast Nigeria.

\begin{tabular}{|c|c|c|c|c|}
\hline Senatorial zone & $\begin{array}{c}\text { Local government } \\
\text { area }\end{array}$ & $\begin{array}{c}\text { No. of serum } \\
\text { samples tested }\end{array}$ & $\begin{array}{l}\text { No. of serum samples } \\
\text { positive to ND } \\
\text { antibodies (\%) }\end{array}$ & $\begin{array}{c}\text { No. of serum samples } \\
\text { negative to ND } \\
\text { antibodies ( } \%)\end{array}$ \\
\hline Enugu East & $\mathrm{EE}, \mathrm{EN}, \mathrm{ES}$ & 185 & $60(32.4)$ & $125(67.6)$ \\
\hline Enugu West & UD, EZ, AG & 175 & $53(30.2)$ & $122(69.8)$ \\
\hline \multirow[t]{2}{*}{ Enugu North } & NS, IGE, IGZ & 209 & 73 (34.9) & $136(65.1)$ \\
\hline & Total & 569 & $186(32.7)$ & $383(67.3)$ \\
\hline
\end{tabular}

$\mathrm{EE}=$ Enugu East, EN=Enugu North, ES=Enugu South, UD=Udi, EZ=Ezeagu, AG=Agwu, NS=Nsukka, IGE=Igbo-Etiti, IGZ=Igbo-Eze

Table-2: Distribution of mean $\mathrm{HI}$ antibody titer against Newcastle disease virus in free-range turkeys in the three senatorial zones of Enugu state, Southeast Nigeria.

\begin{tabular}{lccc}
\hline $\begin{array}{l}\text { Senatorial zone in Enugu } \\
\text { state, Southeast Nigeria }\end{array}$ & Local government area & $\begin{array}{c}\text { Number of serum } \\
\text { samples tested }\end{array}$ & Mean HI titer \\
\hline Enugu East & EE, EN, ES & 185 & $579.41 \pm 98.46^{\mathrm{a}}$ \\
Enugu West & UD, EZ, AG & 175 & $61.89 \pm 11.69^{\mathrm{b}}$ \\
Enugu North & NS, IGE, IGZ & 209 & $85.92 \pm 28.58^{\mathrm{b}}$ \\
& Total & 569 & \\
\hline
\end{tabular}

$\mathrm{EE}=$ Enugu East, EN=Enugu North, ES=Enugu South, UD=Udi, EZ=Ezeagu, AG=Agwu, NS=Nsukka, IGE=Igbo-Etiti, IGZ=Igbo-Eze. Values with different superscripts; $a, b, c$ within the column differ significantly $(p \leq 0.05)$

Table-3: Distribution of Newcastle disease HI antibody titers in turkeys reared in Enugu state, Southeast Nigeria.

\begin{tabular}{|c|c|c|c|}
\hline \multirow{3}{*}{$\begin{array}{l}\text { Senatorial } \\
\text { zones }\end{array}$} & \multirow{3}{*}{$\begin{array}{c}\text { Number } \\
\text { of }+ \text { ve } \\
\text { sera }\end{array}$} & Titer & Titers \\
\hline & & $<8$ & $\geq 8$ \\
\hline & & Not protected & Protected \\
\hline East Enugu & 60 & 7 & 53 \\
\hline Enugu West & 53 & 17 & 36 \\
\hline Enugu North & 73 & 24 & 49 \\
\hline Total & 186 & 48 & 138 \\
\hline
\end{tabular}

$\mathrm{HI}$ titers $\geq 8$ were considered protective. (OIE, 2012)

suggests that the turkeys may have been exposed to NDV either through the ingestion of contaminated feed or water, inhalation of the virus, contact with other infected birds, or contact with fomites [24]. In this study, turkeys that tested positive for ND may be those that recovered from an outbreak of ND or were purchased from other areas that had outbreaks because vaccination of village poultry is rarely undertaken [25]. These turkeys could act as reservoirs of NDV [14,24,26,27]. The detection of ND hemagglutinating antibodies in turkeys that were sampled in the present study and in a previous study in Kaduna state, Nigeria [28], suggests that circulation of NDV in turkeys in the southeastern and northern parts of Nigeria may be influenced by the movement of local poultry and poultry products from the north to the southeast and vice versa.

A seroprevalence of $32.7 \%$ in turkeys in Southeast Nigeria in the present study is at variance with $68 \%, 57.2 \%$, and $53.7 \%$ recorded from turkeys in the Nigerian cities of Zaria (north-central), Maiduguri (northeastern), and Gombe (northern) [16,17,19], respectively. These observed regional differences in ND prevalence show an ecological variation in NDV activity and may be a reflection of the impact of the environment on the viability, spread, and epidemiology of NDV $[29,30]$. The lower seroprevalence value of $32.7 \%$ recorded in turkeys in Southeast Nigeria in comparison with $60.7 \%$ value recorded from local chickens previously sampled in the same zone [31] suggests that NDV infection in chickens is more severe than that in turkeys, and turkeys are likely to be sources of infection for other species, especially chickens.

The widespread presence of NDV antibodies in turkeys, as demonstrated in this study, implies that husbandry practices (backyard and commercial poultry) where different species of poultry, including turkeys are reared together may encourage cross-infection with NDV among the different species. This risk may be higher in areas where NDV vaccination is not commonly practiced as in the case of local or household poultry. From this study, $67.3 \%$ of the turkeys sampled that had no detectable antibodies against ND in addition to $25.9 \%$ of the turkeys with ND-positive serum and HI titers $<8$ are presumed at risk and may not be protected against a challenge from a virulent strain of ND [23]. Researchers have reported that the risk of infection in such unprotected turkeys could be reduced by NDV vaccination [32-34].

The very high antibody titers against ND that we recorded in the east senatorial zone of Enugu when compared with the other two other zones are a reflection of the high density of poultry farms in East Enugu, which includes Enugu urban and neighboring towns and villages. It also implies that the epidemiology of the disease among zones varies with the highest chances of NDV transmission occurring in areas where other poultry species are reared with unvaccinated turkeys [17]. 
Table-4: Virus detection from cloacal swab of turkeys sampled in Enugu state, Southeast Nigeria.

\begin{tabular}{llccccccc}
\hline Senatorial zones & Local government area & HLD 1 & HLD2 & HLD3 & HLD4 & HLD5 & HLD6 & HLD7 \\
\hline Enugu East & EE & $20 / 20$ & $0 / 20$ & $0 / 20$ & $9 / 9$ & $0 / 14$ & $0 / 13$ & $0 / 14$ \\
& EN & $10 / 10$ & $0 / 10$ & $0 / 10$ & $0 / 6$ & $3 / 3$ & - & - \\
\multirow{3}{*}{ Enugu West } & ES & $10 / 10$ & $0 / 8$ & $8 / 8$ & $0 / 5$ & $0 / 5$ & - & - \\
& UD & $0 / 15$ & $10 / 10$ & $0 / 12$ & $0 / 4$ & $9 / 9$ & - & - \\
\multirow{3}{*}{ Enugu North } & EZ & $0 / 10$ & $0 / 20$ & $9 / 9$ & $0 / 16$ & $2 / 2$ & - & - \\
& AG & $20 / 20$ & $0 / 20$ & $0 / 15$ & $0 / 10$ & $3 / 3$ & - & - \\
& NS & $20 / 20$ & $20 / 20$ & $0 / 20$ & $0 / 20$ & $0 / 20$ & $0 / 20$ & $0 / 16$ \\
& IGE & $9 / 9$ & $0 / 7$ & $10 / 10$ & $0 / 10$ & $2 / 2$ & - & - \\
\hline
\end{tabular}

$\mathrm{EE}=$ Enugu East, $\mathrm{EN}=$ Enugu North, ES=Enugu South, UD=Udi, EZ=Ezeagu, AG=Agwu, NS=Nsukka, IGE=Igbo-Etiti, IGZ=Igbo-Eze, HLD=Household visited

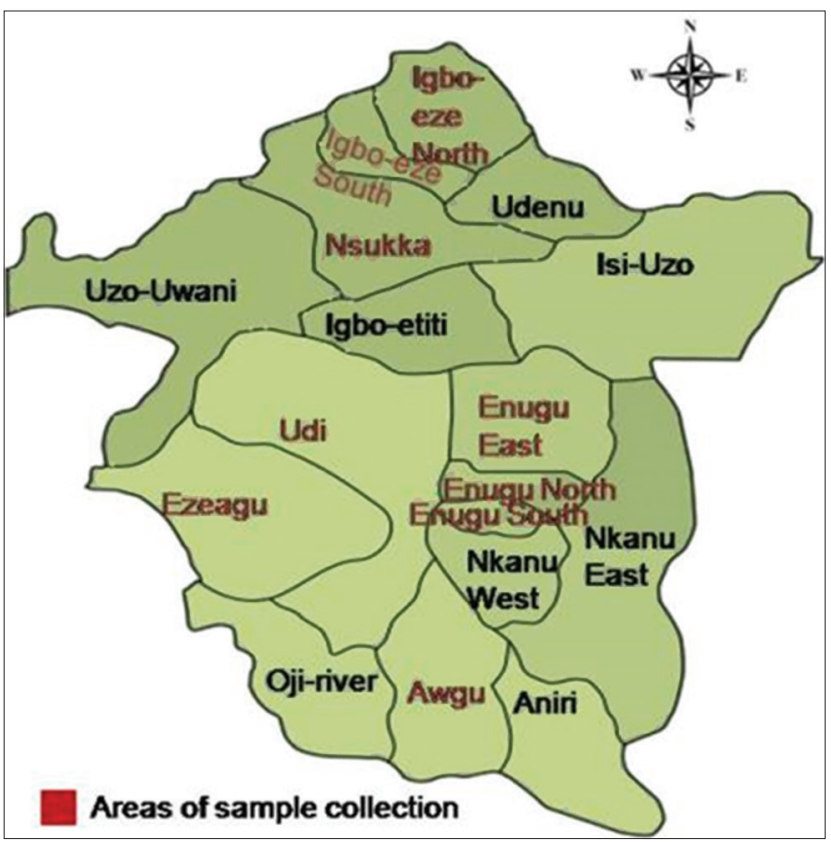

Figure-1: Map of Enugu state showing the areas of sample location.

Detection of NDV in the feces of ND-positive turkeys sampled in the study area suggests that these turkeys appeared healthy or have recovered from a mild natural infection that induced a carrier status. This may constitute a potential threat to other species of poultry kept together with these turkeys and suggests that NDV may continually be present and circulate among poultry species in the study area. Furthermore, in our locality, poultry manure is commonly used by peasant farmers in the cultivation of farms which were local chickens and other farm animals scavenge for food. This manure often lodges in the undersides of footwear or the tires of automobiles and, by these means, NDV infection can spread even to commercial poultry farms. The possibility of this mode of spread could be one of the reasons for the sporadic outbreaks witnessed during the dry Harmattan season, which is shortly after the planting season in Nigeria. These sporadic outbreaks of ND occur with high morbidity and mortality, thereby affecting food security, which may result in malnutrition, unemployment, and great losses to backyard poultry keepers. It is, therefore, advised that all species of poultry be vaccinated against NDV.

\section{Conclusion}

Detection of NDV in the serum and feces of turkeys in the Enugu state of Southeast Nigeria should discourage the practice of keeping different bird species together because it increases the chances of NDV transfer across species. Poultry farmers who keep turkeys should be encouraged to routinely vaccinate these birds against NDV.

\section{Authors' Contributions}

ONO conceived the work and conducted the field work with PCA, ECM, and CJA. JAN and BA designed and supervised the study. OON drafted the manuscript, interpreted data and CJA edited the manuscript. JOO reviewed the manuscript. All authors read and approved the final manuscript.

\section{Acknowledgments}

The authors are grateful to Dr. Ekene Ezenduka for providing technical assistance in this study. This study did not receive any external funding.

\section{Competing Interests}

The authors declare that they have no competing interests.

\section{Publisher's Note}

Veterinary World remains neutral with regard to jurisdictional claims in published map and institutional affiliation.

\section{References}

1. Shittu, I., Joannis, T.M., Georgina, N., Odaibo, O. and Olufemi, D. (2016) Newcastle disease in Nigeria: Epizootiology and current knowledge of circulating genotypes. Virus Dis., 27(4): 329-339.

2. Walker, P.J., Siddell, S.G., Lefkowitz, E.J., Mushegian, A.R., Dempsey, D.M., Dutilh, B.E., Harrach, B., Harrison, R.L., Hendrickson, R.C., Junglen, S., Knowles, N.J., Kropinski, A.M., Krupovic, M., Kuhn J.H., Nibert, M., Rubion, L., Sabanadzovic, S., Simmonds, P., Varsani, A., Zerbini, F.M. and Davison, A.J. (2019) Changes to virus taxonomy and the international code of virus classification and nomenclature ratified by the international committee on taxonomy of viruses. Arch. Virol., 164(9):2417-2429.

3. Amarasinghe, G.K., Ceballos, N.G.A., Banyard, A.C., Basler, C.F., Bavari, S., Bennett, A.J., Blasdell, K.R., Briese, T., Bukreyev, A., Cai, Y., Calisher, C.H., Lawson, C.C., Chandran, K., Chapman, C.A., Chiu, C.Y., 
Choi, K.S., Collins, P.L., Dietzgen, R.G., Dolja, V.V., Dolnik, O., Domier, L.L., Dürrwald, R., Dye, J.M., Easton, A.J., Ebihara, H., Echevarría, J.E., Fooks, A.R., Formenty, P.B.H., Fouchier, R.A.M., Freuling, C.M., Ghedin, E., Goldberg, T.L., Hewson, R., Horie, M., Hyndman, T.H., Jiāng, D., Kityo, R., Kobinger, G.P., Kondō, H., Koonin, E.V., Krupovic, M., Kurath, G., Lamb, R.A., Lee, B., Leroy, E.M., Maes, P., Maisner, A., Marston, D.A., Mor, S.K., Müller, T., Mühlberger, E., Ramírez, V.M.N., Netesov, S.V., Ng, T.F.F., Nowotny, N., Palacios, G., Patterson, J.L., Paweska, J.T., Payne, S.L., Prieto, K., Rima, B.K., Rota, P., Rubbenstroth, D., Schwemmle, M., Siddell, S., Smither, S.J., Son, Q., Song, T., Stenglein, M.D., Stone, D.M., Takada, A., Tesh, R.B., Thomazelli, L.M., Tomonaga, K., Tordo, N., Towner, J.S., Vasilakis, N., Vázquez-Morón, S., Verdugo, C., Volchkov, V.E., Wahl, V., Walker, P.J., Wang, D., Wang, L.F., Wellehan, J.F.X., Wiley, M.R., Whitfield, A.E., Wolf, Y.I., Yè, G., Zhāng, Y.Z. and Kuhn, J.H. (2018) Taxonomy of the order Mononegavirales: Update 2018. Arch. Virol., 163(8): 2283-2294.

4. Wakamatsu, N., King, D.J., Kapczynski, D.R., Seal, B.S. and Brown, C.C. (2006) Experimental pathogenesis for chickens, Turkeys and pigeons of exotic NDV from an outbreak in California during 2002-2003. Vet. Pathol., 43(6): 925-933.

5. Dai, Y., Liu, M., Cheng, X., Shen, X., Wei, Y. and Zhou, S. (2014) Infectivity and pathogenicity of Newcastle disease virus strains of different avian origin and different virulence for mallard ducklings. Avian Dis., 57(1): 8-14.

6. Eze, C.P, Okoye, J.O.A, Ogbonna, I.O., Ezema, W.S., Eze, D.C., Okwor, E.C., Okorie-Kanu, C. and Idika, K.I. (2014) Comparative evaluation of the effects of velogenic Newcastle disease virus infection on the hematology of ducks and chickens. Open J. Vet. Med., 4(6): 113-121.

7. Igwe, A.O., Shittu, I. and Okoye, J.O.A. (2018) Response of cyclophosphamide-treated broiler chickens to challenge with velogenic Newcastle disease virus. J. Appl. Anim. Res., 46(1): 938-946.

8. Okoroafor, O.N., Eze, C.P., Ezema, W.S., Nwosu, C., OkorieKanu, C., Animoke, P.C., Anene, B.M. and Okoye, J.O.A. (2018) La Sota vaccination may not protect against virus shedding and the lesions of velogenic Newcastle disease in commercial Turkeys. Trop. Anim. Health Prod., 50(2): 345-351.

9. Nwankiti, O., Ejekwolu, A., Ibrahim, I., Ndako, J. and Echeonwu, G. (2010) Detection of serum antibody levels against Newcastle disease in local chickens in Bauchi metropolis, Bauchi State, Nigeria. Afr. J. Clin. Exp. Microbiol., 11(2): 95-101.

10. Hassan, S.U., El-Yuguda, A.D., Gambo, H.I., Baba, S.S. and Ambali, A.G. (2016) Prevalence of Newcastle disease virus antibodies in sera and eggs of helmeted guinea fowls (Numida meleagris galeata Pallas) in Borno and Yobe States. Niger. J. Vet. Sci., 14(1): 49-52.

11. Echeonwu, G.O.N., Ireogbu, C.I. and Emereuwa, A.C. (1993) Recovery of velogenic Newcastle disease virus from death and healthy free roaming birds in Nigeria. Avian Pathol., 22(2): 383-387.

12. Ramey, A.M., Goraichuk, I.V., Hicks, J.T., Dimitrov, K.M., Poulson, R.M., Stallknecht, D.E., Bahl, J. and Afonso, C.L. (2017) Assessment of contemporary genetic diversity and inter-taxa/inter-region exchange of avian paramyxovirus serotype 1 in wild birds sampled in North America. Virol. J., 14(1): 43.

13. Center for Food Security and Public Health. (2016) IOWA State University College of Veterinary Medicine. Newcastle Disease Avian Paramyxovirus-1 Infection. Center for Food Security and Public Health, European.

14. Mai, H.M., Qadeers, M.A., Bawa, I.A, Sanusi, M. and Tayong, K.N. (2014) Seroprevalence of Newcastle disease in local chickens in Mezam division of North-west Cameroon. Microbiol. Res. Int., 2(1): 9-12.
15. Alexander, D.J., Parsons, G. and Marshall, R. (1984a) Infections of fowls with Newcastle disease virus by food contaminated with pigeon faeces. Vet. Rec., 115(23): 601-602.

16. Sadiq, N.A, Nwanta, J.A., Okolocha, E.C. and Tijiani, O. (2011) Retrospective (1999-2009) study of Newcastle disease cases in Avian species in Maiduguri, Borno State, North Eastern Nigeria. Int. J. Pout. Sci., 10(1): 76-81.

17. Lawal, J.R., El-Yuguda, A.D. and Ibrahim, U.I. (2016) Survey on prevalence of Newcastle disease in village poultry at live birds markets in Gombe, Nigeria. J. Anim. Sci. Livest. Prod., 1(1): 1.

18. Ibrahim, I. and Abdu, P. (1992) Ethno-agroveterinary Perspectives of Poultry Management, Health and Production among the Hausa/Fulani of Rural Nigeria Proceeding of the $29^{\text {th }}$ Annual General Meeting of Nigerian Veterinary Medical Association $27^{\text {th }}-30^{\text {th }}$ October, Kaduna, Nigeria, p172-188.

19. Sa'idu, L., Tekdek, L.B. and Abdu, P.A. (2004) Prevalence of Newcastle disease antibodies in domestic and semi-domestic birds in Zaria, Nigeria. Vet. Arh., 74(4): 309-317.

20. World Organization for Animal Health. (2005) Office International Epizooties Disease Information. Vol. 8. World Organization for Animal Health, Paris, France. Available from: http://www.Oie.int/info/hebdo/AIS59.HTM\#Sec8. Retrieved on 05-01-2019.

21. Thrusfield, M. (2005) Veterinary Epidemiology. $2^{\text {nd }}$ ed. United Kingdom: Black Well Science, p180.

22. Office International des Epizootics. (2012) In: Truszczynski, M., editors. Manual of Diagnostic Tests and Vaccines for Terrestrial Animals: Newcastle Disease. Ch. 23, 14. OIE Standard Commission Publication, Office International Epizooties, Paris, France, p1-19.

23. Office International Epizooties Disease. (2012) Newcastle Disease (Infection with Newcastle Disease Virus). Manual of Diagnostic Tests and Vaccines for Terrestrial Animals: (Mammals, Birds and Bees). Vol. 1. Office International Epizooties Disease, Paris, France, p555-574.

24. Ameji, O.N., Sa'idu, L. and Abdu, P.A. (2016) Survey for Newcastle disease viruses in poultry and wild birds in Kogi state, Nigeria. Iraqi J. Vet. Sci., 14(3): 47-53.

25. Anzaku, S.A., Umoh, J.U., Abdu, P.A, Kabir, J. and Akawu, B. (2017) Serological survey of Newcastle disease in free ranging local chickens in the federal capital territory, Abuja, Nigeria. New J. Sci., 2017: 9646138.

26. Aziz-ul-R, Momena, H. and Muhammad, Z.S. (2018) Adaptation of Newcastle disease virus (NDV) in feral birds and their potential role in interspecies transmission. Open Virol. J., 12(12): 52-68.

27. Olabode, H.O.K., Damina, M.S., Ahmed, A.S., Moses, G.D. and Wungak, Y.S. (2012) Study of Newcastle disease in commercial poultry farms in Ilorin, Kwara state Nigeria. Vom J. Vet. Sci., 9: 66-70.

28. Sa'idu, L., Tekdek, L.B. and Abdu, P.A. (2006) Response of local breeds of chicken to challenge with Newcastle disease virus (KUDU 113 strain). J. Anim. Vet. Adv., 5(11): 975-979.

29. Orajaka, L.J.E., Adene, D.F., Anene, B.M. and Onuoha, E.A. (1999) Seroprevalence of Newcastle disease virus in local chickens from Southeast derived savannah zone of Nigeria. Rev. Elev. Med. Vet. Pays Trop., 52(3-4): 185-188.

30. Dimitrov, K.M., Ramey, A.M., Qiu, X., Bahl, J. and Afonso, C.L. (2016) Temporal, geographic, and host of avian paramyxovirus 1 (Newcastle disease virus). Infect. Genet. Evol., 39: 22-34.

31. Eze, I.A. and Ike, A.C. (2015) The serological status of local chickens of live birds market and household in Nsukka Enugu state, Nigeria. J. Microbiol., 29: 3096-3104.

32. Fentie, T., Dadi, K., Kassa, T., Sahle, M. and Cattoli, G. (2014) Effect of vaccination on transmission characteristics of highly virulent Newcastle disease virus in experimentally infected chickens. Avian Pathol., 43(5): 420-426. 
33. Habibi, H., Nili, H., Asasi, K., Mosleh, N., Firouzi, S. and Mohammadi, M. (2015) Efficacy and transmissibility of Newcastle disease I-2 vaccine strain against a field isolate of virulent ND virus (JF820294.1) in village chicken. Trop. Anim. Health Prod., 47(1): 73-78.
34. Reta, D.A., Kasuhum, A., Olana, M., Yilkal, A.E., Sayes, G., Meta, Y. and Tesha, S. (2016) Serological evaluation in chickens exposed to grains coated with 12 ND virus for effective oral vaccination of village chickens. BMC Vet. Res., 12(1): 150 .

$* * * * * * * *$ 